\title{
SHARING OF ANTIGENS BETWEEN Plasmodium falciparum AND Anopheles albimanus
}

\author{
Albina WIDE(1,2), Jacinta CAPALDO(2), Noraida ZERPA(3), Rosalba PABON(2), Alfredo NODA(2), Belkis NOYA(1), Julio GONZÁLEZ(2)\& Oscar NOYA(1,2)
}

\section{SUMMARY}

The presence of common antigens between Plasmodium falciparum and Anopheles albimanus was demonstrated. Different groups of rabbits were immunized with: crude extract from female An. albimanus (EAaF), red blood cells infected with Plasmodium falciparum (EPfs), and the SPf66 synthetic malaria vaccine. The rabbit's polyclonal antibodies were evaluated by ELISA, Multiple Antigen Blot Assay (MABA), and immunoblotting. All extracts were immunogenic in rabbits according to these three techniques, when they were evaluated against the homologous antigens. Ten molecules were identified in female mosquitoes and also in $P$. falciparum antigens by the autologous sera. The electrophoretic pattern by SDS-PAGE was different for the three antigens evaluated. Cross-reactions between An. albimanus and P. falciparum were found by ELISA, MABA, and immunoblotting. Anti-P. falciparum and anti-SPf66 antibodies recognized ten and five components in the EAaF crude extract, respectively. Likewise, immune sera against female An. albimanus identified four molecules in the P. falciparum extract antigen. As far as we know, this is the first work that demonstrates shared antigens between anophelines and malaria parasites. This finding could be useful for diagnosis, vaccines, and the study of physiology of the immune response to malaria.

KEYWORDS: Anopheles albimanus; Plasmodium falciparum; Shared antigens; Cross-reaction; Multiple Antigen Blot Assay (MABA).

\section{INTRODUCTION}

Several studies have reported that, during the process of coevolution, parasites have shared and expressed equivalent molecules with their hosts. These cross-reactions may probably result from a process of adaptation of these invertebrates to counteract protective immunological mechanisms $s^{3,4,24}$.

Specifically, these shared antigens between parasites and their hosts have been demonstrated among different species of trematodes and their intermediate hosts $8,9,10,16,17,29,45$. One of them is tropomyosin, a protein shared by $S$. mansoni and its intermediate host Biomphalaria glabrata $^{20}$.

It has been proposed that the presence of common antigens between some parasites and their hosts would facilitate the search for candidate vaccines and diagnostic targets, when observing the abundance of antigenic material that can be obtained from those hosts, as demonstrated in schistosomiasis. The existence of shared antigens between Schistosoma and Biomphalaria has been shown by the presence of anti-Biomphalaria antibodies in experimental animals infected with the parasite. The opposite has also been demonstrated in animals immunized with uninfected snails, which have shown anti-Schistosoma antibodies. Additionally, anti-Biomphalaria antibodies have been found in infected humans with Schistosoma mansoni ${ }^{1,18,19,22,25,27,33}$.

Malaria is a vector-borne disease transmitted through the bite of anopheline mosquitoes, the only genus that transmits human malaria ${ }^{26,47}$. In America, the most important species of Anopheles are: An. darlingi, An. albimanus, An. aquasalis, and An. pseudopunctipennis ${ }^{23}$. However, so far, no study has been carried out to determine shared antigens between Plasmodium and their vectors.

For this reason, the purpose of this research is to identify shared antigens between An. albimanus and P. falciparum that could have potential relevance in immunodiagnosis and immunoprophylaxis of malaria. It is also useful in explaining false positive results observed against malaria antigens in individuals who were exposed to multiple anopheline bites. In preliminary studies carried out with humans who did not have any previous malaric episodes and who come from a non endemic area in Venezuela, a percentage of seropositivity against molecules from An. albimanus and P. falciparum crude extracts was found (unpublished results). The identification of common antigens between the parasite and its vector could be of value in a multi-target vaccine (anti-parasite and anti-vector), once the feasibility of antiarthropod vaccines is demonstrated ${ }^{11,44}$.

(1) Escuela de Medicina "Luis Razetti", Cátedra de Parasitología, Instituto de Medicina Tropical, Facultad de Medicina, Universidad Central de Venezuela, Apartado postal 47623, Los Chaguaramos 1041-A, Caracas, Venezuela.

(2) Laboratorio para Estudios sobre Malaria, Instituto de Altos Estudios en Salud Pública "Dr. Arnoldo Gabaldón”, and Instituto Nacional de Higiene from the Ministerio de Salud y Desarrollo Social, Caracas, Venezuela.

(3) Instituto de Estudios Avanzados, Caracas, Venezuela.

Correspondence to: Prof. Albina Wide, Instituto de Medicina Tropical, Cátedra de Parasitología, Facultad de Medicina. Escuela de Medicina "Luis Razetti", Universidad Central de Venezuela, Apartado 47623, Caracas 1041-A, Venezuela. Fax: +58-212-6930454. E-mail: albina_wide@yahoo.com 


\section{MATERIALS AND METHODS}

Source of adult An. albimanus mosquitoes: A mosquito colony from An. albimanus was maintained in the laboratory according to the methodology described by ZERPA et al. ${ }^{46}$.

Preparation of An. albimanus crude extract antigen: A crude anopheline preparation was obtained from female mosquitoes (EAaF) five to six days old. Female newborn mosquitoes were fed only with sugar solution until the moment of the extract preparation. None of the mosquitoes were exposed to a blood meal. These were immobilized by exposure to a temperature below $0{ }^{\circ} \mathrm{C}$, during $15 \mathrm{~min}$ in a freezer. Afterwards, legs and wings were removed without damaging the abdomen, thorax and head. Each lot of antigen was prepared with 25 mosquitoes and homogenized in $0.5 \mathrm{~mL}$ of saline solution $0.85 \%$ (w/ v) with a homogenizer (Potter Eveljhan), through 30 cycles as described by ALGER \& CABRERA ${ }^{2}$ and SUTHERLAND \& EWEN ${ }^{38}$. After the homogenization, the mosquito extract was sonicated in a Braun-Sonic 1510 (B. Braun Melsungen AG) at 100 watts, using six cycles of one min each at $5{ }^{\circ} \mathrm{C}$. The sonicated sample was centrifuged at 4,960 $\mathrm{g}$ for one $\mathrm{h}$ at $5{ }^{\circ} \mathrm{C}$. Finally, one extract was obtained by mixing all the preparations from the same colony of mosquitoes, and then, only the supernatant was used as antigen.

Preparation of Plasmodium falciparum antigen: P. falciparum ( $\mathrm{FCB}_{2}$ strain) parasites were obtained from continuous in vitro culture with a parasitemia of $10 \%$ to $12 \%$, according to the methodology of TRAGER \& JENSEN ${ }^{41}$. Parasites were concentrated by a discontinuous gradient of Percoll: 75\% (v/v), 60\% (v/v), 40\% (v/v) as described by KRAMER et al. ${ }^{28}$ and RIVADENEIRA et al. ${ }^{35}$. The layer of cells enriched with parasitized red blood cells (PRBC) was centrifuged at $861 \mathrm{~g}$ for $15 \mathrm{~min}$ at $4{ }^{\circ} \mathrm{C}$. Three types of $P$. falciparum antigens were obtained: (a) Crude extract (EPfd) obtained with detergent: PRBC were treated with saponin solution at $0.2 \%(\mathrm{w} / \mathrm{v})$ in a $7: 1$ ratio, strongly stirred during $20 \mathrm{~s}$ and centrifuged at $1,240 \mathrm{~g}$ for $10 \mathrm{~min}$. After two washes in PBS at 1,240 g X $10 \mathrm{~min}$, the pellet containing parasites and the ghost red blood cells were collected. The PRBC lysis was completed by treating with a buffer solution, containing SDS at $10 \%(\mathrm{v} / \mathrm{v})$, EDTA 1M, PMSF $100 \mathrm{mM}$ or $300 \mu \mathrm{L}$ Protease Inhibitor Cocktails (Sigma, P 2714), in a 7:1 ratio, and thereafter by shaking with a vortex at maximum speed during five min. Finally, the homogenate was centrifuged at $15,800 \mathrm{~g}$ in a microcentrifuge for $20 \mathrm{~min}$, discarding the pellet and keeping the supernatant according to SALCEDO et al. ${ }^{37}$. This extract was used for the assays. (b) Crude extract obtained by sonication (EPfs): The PRBC was resuspended in $1 \mathrm{~mL}$ of PBS-Dulbecco and sonicated in a Braun-Sonic 1510 (B. Braun Melsungen AG) at 100 watts by six cycles of one min each at $5{ }^{\circ} \mathrm{C}$. Thereafter, it was centrifuged at 12,000 $\mathrm{g}$ for $30 \mathrm{~min}$, discarding the pellet and keeping the supernatant. Only one extract was prepared by this methodology and used as antigen. (c) Preparation of culture Supernatant (Spt) antigen: In vitro culture of $P$. falciparum was centrifuged at $1,240 \mathrm{~g}$ for $10 \mathrm{~min}$ at $4{ }^{\circ} \mathrm{C}$, and the supernatant obtained was used as the control antigen in MABA. Protein concentration of the different antigen preparations was quantified following the BRADFORD ${ }^{5}$ method.

Immunization of rabbits: Three months old New Zealand rabbits were injected subcutaneously with $0.5 \mathrm{mg}$ of SPf66 vaccine, $0.5 \mathrm{mg}$ of EPfs, or $1 \mathrm{mg}$ of EAaF extracts, emulsified in Complete Freund's
Adjuvant (CFA) for the first dose and with Incomplete Freund's Adjuvant (IFA) for the subsequent two doses every 15 days (1:1 ratio $\mathrm{vol} / \mathrm{vol}$ of antigen/adjuvant). EPfs (extract obtained by sonication) was used for immunization because it had no detergent, and it was the most enriched with parasite material. Rabbits immunized with SPf66 vaccine were boosted six times. Bleeding of rabbits, previously anesthetized with $10 \mathrm{mg} / \mathrm{kg}$ Ketamine Chlorhydrate, was carried out before the first immunization and 10 days after the third dose.

Preparation of red blood cells ( $R B C)$ : $\mathrm{RBC}$ antigen was obtained with the same methodology for EPfd as described by SALCEDO et al. ${ }^{37}$.

Immunogenicity and cross-reaction of An. albimanus and $P$. falciparum extracts: The detection of specific anti-mosquito and antiPlasmodium rabbit antibodies was carried out by ELISA, as described by ENGVALL \& PERLMANN ${ }^{21}$ and by VOLLER et $a l^{42}$, with a protein concentration of $7 \mu \mathrm{g} / \mathrm{well}$ for the An. albimanus antigen (EAaF), $3 \mu \mathrm{g} / \mathrm{well}$ for the $P$. falciparum antigen (EPfs), and $1 \mu \mathrm{g} / \mathrm{well}$ for the SPf66 vaccine. Additionally, the multiple antigen blot assay (MABA), described by NOYA \& ALARCÓN DE NOYA ${ }^{30}$, was used, sensitizing the nitrocellulose membrane with protein (between five and $20 \mu \mathrm{g} / \mathrm{mL}$ ). The immune sera were also evaluated by Immunoblotting ${ }^{40}$ at a dilution of 1:50 for anti-SPf66 vaccine and 1:100 for anti-female mosquito (EAaF) and anti-P. falciparum (EPfs). The protein concentration of the different antigenic preparations (EPfd, EPfs, EAaF, and $\mathrm{RBC}$ ) used for immunoblotting was $1.0 \mu \mathrm{g} / \mu \mathrm{L}$. Anti-IgG rabbit conjugated peroxidase was used at a 1:4000 dilution. A chemiluminiscent substrate Luminol ${ }^{\circledR}$ was used (Amersham, ECL Detection System). Strips were then exposed to a film (Hyperfilm ${ }^{\circledR}$, ECL Detection System, Amersham).

Statistical analysis: Statistical comparisons using median and standard deviation were made. Three experiments were performed by enzyme-linked immunosorbent assay (ELISA).

\section{RESULTS}

Electrophoretic pattern by SDS-PAGE: Silver stained An. albimanus mosquito crude extracts revealed sixteen protein bands for the female antigen (EAaF), ranging from 24 to $95 \mathrm{kDa}$. In the $P$. falciparum preparation (EPfd), there were eighteen molecules between 26 to $161 \mathrm{kDa}$ (data not shown).

Immunogenicity of An. albimanus female mosquitoes, $P$. falciparum and SPf66 antigen preparations: Immune rabbit sera against EPfs, SPf66 vaccine, or EAaF, evaluated by MABA are shown in Fig. 1 and by ELISA in Fig. 2. Evaluations done by immunoblotting are shown in Fig. 3.

Ten antigenic components were revealed in EAaF extract (apparent molecular weight from 30 to $124 \mathrm{kDa}$ ) by anti-EAaF sera (Fig. 3). Likewise, anti-EPfs sera recognized ten antigenic molecules between 12 to $143 \mathrm{kDa}$ in EPfd (Fig. 3).

Cross-reaction by MABA: Rabbits immunized with EPfs recognized the following antigens: excretory-secretory in the culture supernatant of P. falciparum (Spt), EAaF, SPf66 vaccine, and normal 


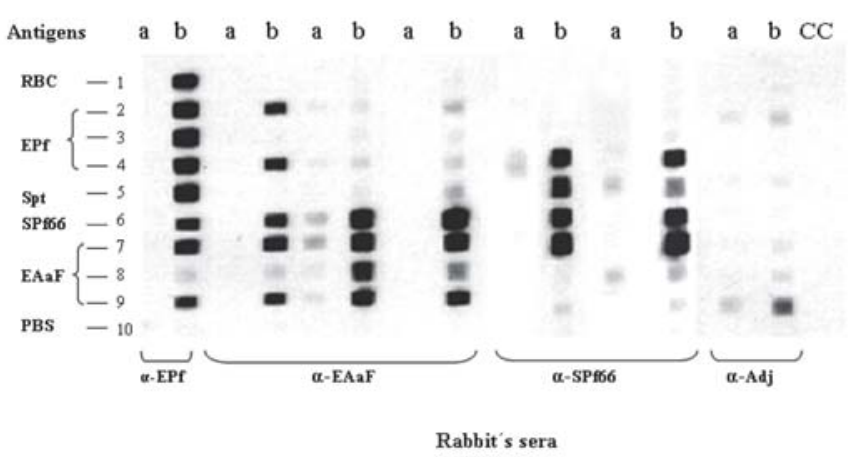

Fig. 1 - Immunogenicity and cross-reactivity of Plasmodium falciparum and Anopheles albimanus crude extracts, evaluated by MABA. RBC: Red Blood Cells (1), EPf: extract of RBC parasitized with $P$. falciparum treated with saponin detergent (2) and sonicated (3 and 4) with concentration of $5 \mu \mathrm{g} / \mathrm{mL}$ and $20 \mu \mathrm{g} / \mathrm{mL}$ respectively. Spt: Supernatant of culture $P$. falciparum (5). SPf66: Vaccine anti-P. falciparum (6). EAaF: Extract of An. albimanus female with concentration of: $20 \mu \mathrm{g} / \mathrm{mL}$ (7), $5 \mu \mathrm{g} / \mathrm{mL}$ (8) and $10 \mu \mathrm{g} / \mathrm{mL}$ (9), PBS (10). Preimmune serum (a), Immune sera (b). Adj: Adjuvant. CC: Control of conjugate.

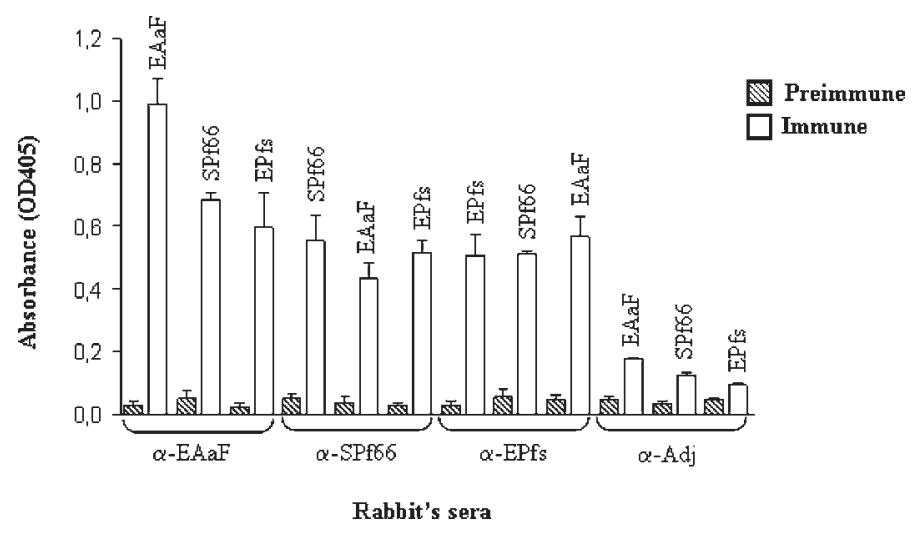

Fig. 2 - Immunogenicity (homologous sera) and antigen cross-reactivity (heterologous sera) between P. falciparum and An. albimanus by ELISA. Rabbit's sera immunized with: Extract of An. albimanus female (EAaF) or Extract of P. falciparum by sonication (EPfs) or Vaccine malaria (SPf66). Preimmune serum (a), Immune sera (b). Adj: Adjuvant. CC: Control of conjugate. OD405: optical density at $405 \mathrm{~nm}$. T: Standard deviation.

RBC components (Fig. 1). Rabbits immunized with EAaF recognized P. falciparum and SPf66 vaccine preparations (Fig. 1). Finally, rabbits immunized with SPf66 vaccine recognized one or more components in the culture supernatant of P. falciparum, EAaF, EPfs, and EPfd (Fig. 1). Noteworthy, only rabbit sera immunized with EPfs recognized RBC. The rest of the sera groups did not react with this antigen preparation.

Cross-reaction of P. falciparum and An. albimanus by ELISA: A reciprocal recognition was observed among the three extracts in rabbits immunized with the heterologous antigens. The crude EAaF was recognized by rabbit sera immunized with EPfs or SPf66, and similarly, the crude EPfs was identified by anti-EAaF and anti-SPf66. Moreover, the SPf66 vaccine was recognized by anti- EAaF and anti-EPfs antigen immune sera (Fig. 2). Weak non-specific antibody responses were observed with control rabbits immunized only with adjuvant.

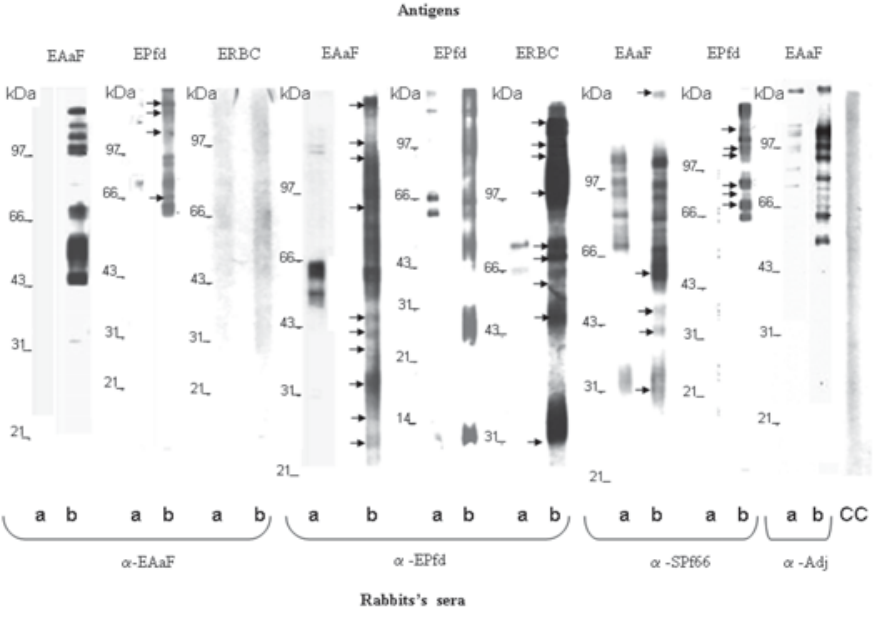

Fig. 3 - Pattern of antigenic recognition of An. albimanus female extract (EAaF), P. falciparum treated with saponin (EPfd) and Red Blod Cell extract by rabbit sera: anti-EAaF, anti-EPfs (P. falciparum treated by sonication) and anti-SPf66, by immunoblotting. Adj: Adjuvant, CC: Conjugate Control, a: Pre-immune sera, b: Immune sera.

Cross-reaction by immunoblotting: The anti-EAaF rabbit sera recognized ten protein bands in the EPfd from 63 to $159 \mathrm{kDa}$, specifically 68, 110, 136, and $159 \mathrm{kDa}$ bands (Fig. 3). The anti-EPfs reacted with fourteen protein bands in the EAaF between 25 and 160 $\mathrm{kDa}$, ten of them being specifics with molecular weights of $25,27,36$, $42,44,49,83,110,118$, and $160 \mathrm{kDa}$ (Fig. 3). The anti-EPfs recognized nine molecules: 32, 53, 65, 70, 74, 99, 118, 126, and 130 (duplet) $\mathrm{kDa}$ in the RBC fraction (Fig. 3). Anti-SPf66 vaccine reacted with thirteen protein bands in the $\mathrm{EAaF}$ ranging from 31 to $152 \mathrm{kDa}$, with only five specific molecules: 31, 42, 44, 61, and $152 \mathrm{kDa}$ (Fig. 3). The antiSPf66 rabbit recognized ten bands in EPfd, from 64 to $132 \mathrm{kDa}$. The most specific molecules were: 70, 77, 82, 106, 110, and $127 \mathrm{kDa}$ (Fig. 3). Some protein bands with molecular weights around $65,74,99 \mathrm{kDa}$ are also present in rabbits immunized only with CFA and IFA (data not shown). These bands were excluded from analysis of specificity.

\section{DISCUSSION}

The Schistosoma-Biomphalaria association was the first hostparasite model which demonstrated shared antigens ${ }^{8,22,43}$. Different molecules are cross-reactive and most of them have not been characterized yet. Tropomyosin is one of the few molecules characterized and it is shared by S. mansoni and B. glabrata $^{20}$.

Since then, there are different epidemiological studies in which the presence of cross-reactive antibodies were observed ${ }^{1,10,36}$. More recently, the presence of two antigenic components from $B$. glabrata were recognized by mice sera, immunized with a crude antigen from $S$. mansoni adult worm (AWA), by immunoblotting ${ }^{13}$.

Other models in which antigenic sharing between parasites and their intermediate hosts (snails) or vectors has been described: $S$. haematobium, S. japonicum, and Paragonimus westermani, Leishmania major and Phlebotomus duboscqi ${ }^{9,27,28,33,39,43}$. 
The purpose of this study is to identify shared antigens in another model: An. albimanus - P. falciparum.

Rabbits immunized with EPfs reacted strongly with the EAaF. Furthermore, rabbits immunized with female An. albimanus extracts recognized molecular components in only one of the two sonicated EPf. This was expected, however, the protein concentrations were different. The cross-recognition of possible common molecular components between these two organisms was also confirmed by ELISA and MABA assays. These anti-mosquito sera not only recognized molecular components of the $P$. falciparum antigen, but unexpectedly, also identified the SPf66 synthetic malaria vaccine, which contains short sequences of four distinct surface molecules: one from the sporozoite (NANP) and three from the asexual blood stages $(83,55$, $33 \mathrm{kDa}$ ) of the parasite ${ }^{31,32}$. This findings deserves special attention and further experiments will be required to evaluate the possible antianopheline effect of this well-known protective vaccine $e^{31,32}$.

Also, it would be interesting to identify the topography of the antigens involved in the cross-reactivity in anophelines. A complementary support of the cross-reactivity observed in this study would be provided by cross-absorption of the antisera, with homologous and heterologous antigens, before testing them against both antigens.

It was expected to find a major recognition of the molecular components in the female mosquito extract because of the biochemical complexity of the digestive system. However, the low recognition of these molecules by the homologous or heterologous immune sera could be attributed to different reasons. Firstly, the enriched proteases content required for the digestion of the blood meal could cleave some proteins during the preparation of the extract and it could inhibit the antigenicity of them ${ }^{12}$. Although some extracts were prepared with protease inhibitors, the results obtained in both cases were similar. Secondly, it could be that proteases from the midgut and saliva of anophelines might induce immune suppression in the immunized rabbits. In fact, it has been demonstrated at the experimental level in the murine model, that the initial secretion of IL- 2 or $\gamma$-interferon by TH1 cells can be suppressed by components present in the salivary gland extracts of Aedes aegypti and Simulium vittatum mosquitoes ${ }^{14,15}$.

Another possibility is that, the selection of an anti-IgG conjugate might have occluded the response to other important isotypes (IgM and $\operatorname{IgE})$.

Moreover, the immunization with Complete and IFA adjuvants could induce a predominantly TH1 response, which is not the habitual immune reactivity to allergenic components of mosquito saliva. The presence of specific $\mathrm{IgE}$ and $\mathrm{IgG}_{4}$ antibodies has been shown to be the main serological response induced in mice, rabbits, and humans against Aedes aegypti, Ae. communis and An. stephensi saliva ${ }^{6,734}$. Therefore, it will be necessary to evaluate the presence of specific anti-mosquito $\mathrm{IgE}$ and $\mathrm{IgG}_{4}$ antibodies as well.

In summary, the study of the shared antigens of any parasite-host model should have three fundamental objectives: (i) In terms of vaccines, the possibility to induce simultaneous protection against the pathogenic agent and its vector; (ii) In terms of diagnosis, to eliminate those molecules responsible for inespecificity of any immunoassay, since exposure to the saliva of the vectors could be responsible for some false positive serology, as we have observed already in persons not exposed to malaria; (iii) In terms of parasite-host interactions, to elucidate the possible role of common molecules involved in immune evasion and immune modulation.

As far as we know, this is the first study to demonstrate sharing antigens between Plasmodium and anopheline vectors. The results presented herein not only could help to understand vector-parasite interactions, but could also contribute to elucidate and to interpret serological tests and immunoepidemiological data related to this parasitic disease.

\section{RESUMEN}

\section{Antígenos compartidos entre Plasmodium falciparum y Anopheles albimanus}

Epítopes de antígenos compartidos entre Plasmodium falciparum y Anopheles albimanus fueron identificados. Diferentes grupos de conejos fueron inmunizados con: extracto crudo de mosquito hembra de $A n$. albimanus (EAaH), glóbulos rojos infectados con P. falciparum (EPfs) y la vacuna antimalárica sintética SPf66. Los anticuerpos policlonales producidos en conejos fueron evaluados por ELISA, inmunoensayo simultáneo de múltiples antígenos (MABA) e Immunoblotting. Todos los extractos resultaron inmunogénicos cuando se evaluaron por ELISA, MABA e Immunoblotting. Diez moléculas fueron identificadas en los mosquitos hembras y diez en los antígenos de $P$. falciparum por los sueros autólogos. El patrón electroforético por SDS-EGPA fue diferente para los tres antígenos evaluados. La reactividad cruzada de moléculas entre An. albimanus y P. falciparum fue demostrada por ELISA, MABA e Immunoblotting. Anticuerpos anti-P. falciparum y anti-SPf66 reconocieron diez y cinco componentes respectivamente en el extracto crudo de anofelinos (EAaH). Asimismo, sueros inmunes contra $A n$. albimanus hembra identificaron cuatro moléculas en el extracto del antígeno de $P$. falciparum. Hasta el presente, este es el primer estudio en el que se demuestra la presencia de antígenos compartidos entre anofelinos y los parásitos de malaria. Este hallazgo podría ser de relevancia para el diagnóstico, vacunas e interpretación de la fisiopatología de la respuesta inmunitaria en malaria.

\section{ACKNOWLEDGEMENTS}

We wish to acknowledge the contributions of the Consejo de Desarrollo Científico y Humanístico $(\mathrm{CDCH})$ from the Universidad Central de Venezuela, Caracas, Venezuela. Project PDT- 09-34-420008 for financial support.

\section{REFERENCES}

1. ALARCÓN DE NOYA, B.; COLMENARES, C. \& NOYA, O. - Comunidad antigénica y reactividad cruzada: su repercusión en el diagnóstico y tratamiento de enfermedades parasitarias. Especial referencia a esquistosomiasis. Arch. venez. Farmacol. Ter., 20: 163-171, 2001.

2. ALGER, N.E. \& CABRERA, E.J. - An increase in death rate of Anopheles stephensi fed of rabbits immunized with mosquito antigen. J. econ. Entomol., 61: 165-168, 1972.

3. BILLINGSLEY, P.F. - Approaches to vector control: new and trusted. 2. Molecular target in the insect midgut. Trans. roy. Soc. trop. Med. Hyg., 88: 136-140, 1994. 
WIDE, A.; CAPALDO, J.; ZERPA, N.; PABON, R.; NODA, A.; NOYA, B.; GONZÁLEZ, J. \& NOYA, O. - Sharing of antigens between Plasmodium falciparum and Anopheles albimanus. Rev. Inst. Med. trop. S. Paulo, 48(6): 327-332, 2006.

4. BILLINGSLEY, P.F. - Vector-parasite interactions for vaccine development. Int. J. Parasit., 24: 53-58, 1994.

5. BRADFORD, M.M. - A rapid and sensitive method for the quantification of microgram quantities of protein utilizing the principle of protein-dye binding. Analyt. Biochem., 72: 248-254, 1976

6. BRUMMER-KORVENKONTIO, H.; LAPPALAINEN, P.; REUNALA, T. \& PALOSUO, T. - Detection of mosquito saliva-specific IgE and IgG4 antibodies by immunoblotting. J. Allergy clin. Immunol., 93: 551-555, 1994.

7. BRUMMER-KORVENKONTIO, H.; PALOSUO, T.; FRANÇOIS, G. \& REUNALA, T. - Characterization of Aedes communis, Aedes aegypti and Anopheles stephensi, mosquito saliva antigens by immunoblotting. Int. Arch. Allergy Immunol., 112: 169-174, 1997.

8. CAPRON, A.; BIGUET, J.; ROSE, F. \& VERNES, A. - Les antigènes de Schistosoma mansoni. II. Étude immunoelectrophoretique comparée. De divers stades larvaires et des adultes des deux sexes. Aspects immunologiques des relations hôte-parasite de la cercaire et de l'adulte de Schistosoma mansoni. Ann. Inst. Pasteur (Paris), 109: 798-810, 1965.

9. CAPRON, A.; BIGUET, J.; VERNES, A. \& AFCHAIN, D. - Structure antigénique des helmintes. Aspects immunologiques des relations hôte parasite. Path. et Biol., 16: 121-138, 1968.

10. CAPRON, A.; BIGUET, J.; TRAN VANKY, P. \& MOSCHETTO, Y. - Immunological studies in various types of schistosomiasis. Ann. N.Y. Acad. Sci., 160: 863-879, 1969.

11. CASTRO, J.J. \& NEWSON, R.M. - Host resistance cattle tick control. Parasit. today, 9: $13-17,1993$.

12. CÁZARES-RAGA, F.E.; SÁNCHEZ-CONTRERAS, M.E.; RODRÍGUEZ, M.H. \& HERNÁNDEZ-HERNÁNDEZ, F.C. - Sex specific proteins and proteases present in the midguts of Anopheles albimanus (Diptera: Culicidae). J. med. Entomol., 35: 184-186, 1998.

13. CHACÓN, N.; LOSADA, S.; NOYA, B.; ALARCÓN DE NOYA, B. \& NOYA O. Antigenic community between Schistosoma mansoni and Biomphalaria glabrata: on the candidate antigens for vaccines. Mem. Inst. Oswaldo Cruz, 97 (suppl. 1): 99-104, 2002.

14. CROSS, M.L.; CUPP, E. \& ENRIQUEZ, F.J. - Differential modulation of murine cellular immune responses by salivary gland extract of Aedes aegypti. Amer. J. trop. Med. Hyg., 51: 690-696, 1994.

15. CROSS, M.L.; CUPP, E.W. \& ENRIQUEZ, F.J. - Modulation of murine cellular immune responses and cytokines by salivary gland extract of the black fly Simulium vittatum. Trop. Med. Parasit., 45: 119-124, 1994.

16. DAMIAN, R.T. - Molecular mimicry: antigen sharing by parasite and host and its consequences. Amer. Naturalist, 98: 129-149, 1964.

17. DAMIAN, R.T. - Molecular mimicry revisited. Parasit. today, 3: 263-266, 1987.

18. DISSOUS, C.; GRZYCH, J.M. \& CAPRÓN, A. - Schistosoma mansoni shares a protective oligosaccharide epitope with freshwater and marine snails. Nature, 323: 443-445, 1986.

19. DISSOUS, C. \& CAPRON, A. - Schistosoma mansoni and its intermediate host Biomphalaria glabrata express a common 39 kilodalton acidic protein. Molec. Biochem. Parasit., 32: 49-56, 1989.

20. DISSOUS, C.; TORPIER, G.; DUVAUX-MIRET, O. \& CAPRON, A. - Structural homology of tropomyosins from the human trematode Schistosoma mansoni and its intermediate host Biomphalaria glabrata. Molec. Biochem. Parasit., 43: 245-255, 1990.
21. ENGVALL, E. \& PERLMANN, P. - Enzyme-linked immunosorbent assay (ELISA). Quantitative assay of immunoglobulin G. Immunochemistry, 8: 871-874, 1971.

22. FAIRLEY, N. H. - Egyptian bilharziasis: its recent pathology, symptomatology and treatment. Proc. roy. Soc. Med., 13: 1-18, 1919-1920.

23. FLEMMING, G. - Biología y Ecología de vectores de la malaria en las Américas. Washington, OPS, 1986. (Ref. PNSP/86-72).

24. GILLESPIE, J.P.; KANOST, M.R. \& TRENCZEK, T. - Biological mediators of insect immunity. Ann. Rev. Entomol., 42: 611-643, 1997.

25. IWANAGA, Y. - Studies on host-parasite relationship between the Puerto Rican strain of Schistosoma mansoni and Biomphalaria snails. Southeast Asian J. trop. Med. publ. Hlth, 25: 509-515, 1994.

26. KNELL, A.J., ed. - Malaria. The tropical programme of the Wellcome trust. Oxford, Oxford University Press, 1991. p. 1-10.

27. KEMP, W.M.; GREENE, N.D. \& DAMIAN, R.T. - Sharing of Cercarienhüllen Reaktion antigens between Schistosoma mansoni cercariae and adults uninfected Biomphalaria pfeifferi. Amer. J. trop. Med. Hyg., 23: 197-202, 1974.

28. KRAMER, K.J.; KAN, S.C. \& SIDDIQUI, W.A. - Concentration of Plasmodium falciparum-infected erythrocyte by density gradient centrifugation in Percoll. J. Parasit., 68: 336-337, 1982.

29. LACKIE, A.M. - Invertebrate immunity. Parasitology, 80: 393-412, 1980

30. NOYA, O. \& ALARCÓN DE NOYA, B. - The multiple antigen blot assay (MABA): a simple immunoenzymatic technique for simultaneous screening of multiple antigens. Immunol. Lett., 63: 53-56, 1998.

31. PATARROYO, M.E.; ROMERO, P.; TORRES, M.L. et al. - Induction of protective immunity against experimental infection with malaria using synthetic peptides. Nature, 328: 629-632, 1987.

32. PATARROYO, M.E.; AMADOR, R.; CLAVIJO, P. et al. - A synthetic vaccine protects humans against challenge with asexual blood stages of Plasmodium falciparum malaria. Nature, 332: 158-161, 1988.

33. RASMUSSEN, K.R.; HILLYER, G.V. \& KEMP, W.M. - Isolation and partial characterization of an antigen shared between Schistosoma mansoni, Fasciola hepatica and Biomphalaria glabrata. J. Parasit., 71: 792-798, 1985.

34. REUNALA, T.; BRUMMER-KORVENKONTIO, H.; PALOSUO, K. et al. - Frequent occurrence of $\mathrm{IgE}$ and $\mathrm{IgG}_{4}$ antibodies against saliva of Aedes communis and Ae. aegypti mosquitoes in children. Int. Arch. Allergy Immunol., 104: 366-371, 1994.

35. RIVADENEIRA, E.M.; WASSERMAN, M. \& ESPINAL, C.T. - Separation and concentration of Schizonts of Plasmodium falciparum by Percoll gradients. J. Protozool., 30: 367-370, 1983.

36. RIVERA-MARRERO, C.A. \& HILLYER, G.V. - Isolation and partial characterization of shared antigens of Biomphalaria glabrata and Schistosoma mansoni and their evaluation by the ELISA and the EITB. J. Parasit., 71: 547-555, 1985.

37. SALCEDO, M.; BARRETO, L.; ROJAS, M. et al. - Studies on the humoral immune response to a synthetic vaccine against Plasmodium falciparum malaria. Clin. exp. Immunol., 84: 122-128, 1991.

38. SUTHERLAND, G.B. \& EWEN, A.B. - Fecundity decrease in mosquitoes ingesting blood from specifically sensitized mammals. J. insect Physiol., 20: 655-660, 1974.

39. TONUI, W.K.; NGUMBI, P.M.; MPOKE, S.S. et al. - Leishmania major-Phleblotomus duboscqi interactions in inhibition of anti-LPG antibodies and characterisation of two proteins with shared epitopes. East African med. J., 81: 97-103, 2004. 
WIDE, A.; CAPALDO, J.; ZERPA, N.; PABON, R.; NODA, A.; NOYA, B.; GONZÁLEZ, J. \& NOYA, O. - Sharing of antigens between Plasmodium falciparum and Anopheles albimanus. Rev. Inst. Med. trop. S. Paulo, 48(6): 327-332, 2006.

40. TWOBIN, H.; STAEHELIN, T. \& GORDON, J. - Electrophoretic transfer of protein from polyacrilamide gels to nitrocellulose sheets: procedure and some applications. Proc. nat. Acad. Sci. (Wash.), 76: 4350-4354, 1979.

41. TRAGER, W. \& JENSEN, J.B. - Human malaria parasites in continuous culture. Science, 193: 673-675, 1976.

42. VOLLER, A.; BIDWELL, B.; HULDT, G. \& ENGVALL, E. - A microplate method of enzyme linked immunosorbent assay and its application to malaria. Bull. Wld Hlth Org., 51: 209-211, 1974.

43. WESTON, D.; ALLEN, B.; THAKUR, A.; LOVERDE, P. \& KEMP, W.M. - Invertebrate host-parasite relationship: convergent evolution of a tropomyosin epitope between Schistosoma spp., Fasciola hepatica and certain pulmonate snails. Exp. Parasit. 78: 269-278, 1994
44. WILLADSEN, P. - Immunological approaches to the control of ticks. Int. J. Parasit. 17: $671-677,1987$.

45. YOSHINO, T.P. \& BAYNE, C.I. - Mimicry of snail host antigens by miracidia and primary sporocysts of Schistosoma mansoni. Paras. Immunol., 5: 317-328, 1983.

46. ZERPA, N.; MORENO, J.; GONZÁLEZ, J. \& NOYA, O. - Colonization and laboratory maintenance of Anhopheles albimanus Wiedemann in Venezuela. Rev. Inst. Med. trop. S. Paulo, 40: 173-176, 1998.

47. ZHENG, L. - Molecular approaches to mosquito parasite interactions. Arch. Insect Biochem. Physiol., 34: 1-18, 1997.

Received: 13 October 2004

Accepted: 29 June 2006 